\title{
研究資料
}

\section{インドネシアにおける新土地家屋税制と その背景}

\section{小 林 英 之*}

1. はじめに

2. 土地制度の概要

3. 建築許可制度と建築の実態

4. 不動産課税の変遷

5. 新たな法律の構成と税制の概要

6. 新税制の目的と新たな方向

7. 最近の動向

8. まとめ

\section{1.はじめに}

インドネシアの政府が，主要な財源芭，海外からの援 助と国営石油公社（プルタミナ）に大きく依存している てとは，周知の事実であるが，1985年の12月27日に公 布され，翌 1 月から施行されるとととなった，新しい 「1985年第12号, 土地・家屋税に関する法律 (UNDANGUNDANG RI NOMOR 12 TAHUN 1985 TENTANG PAJAK BUMI DAN BANGUNAN：(註 1)」は, ての傾向に一つの転機をもたらすものであるように見え る。

本稿では，主に住宅・都市開発の観点から，インドネ シアに打ける従来の市街地の文脈を踏まえつつ，ての新 しい税制の中に認められるいくつかの新しい傾向に関し て考察してみたい。

な拝，筆者の属する建設省建築研究所では，昭和59〜 61 年度にかけて，インドネシア国公共事業省人間居住研 究所と，「インドネシアの都市低所得層のための住宅政 策に関する基礎的研究」を実施して扣り, 本稿の内容の うち，インドネシアの市街地の一般状況に関する記述 は，その際の知見に基づくとてろが大きい。また，特に
建築法規の状況に関しては, 本共同研究の枠組 みの中 で, バンドン工科大学居住環境研究所に委託研究された 成果である報告書（註2）飞負っている。また，乙の共 同研究の枠組みの中で，インドネシアの主要都市の建築 許可部局を訪問し，建築許可の実情に関する聞き取り調 査と, 地方建築条例等の収集若行い, 建設省建築研究所 の一般研究「インドネシアの住宅・都市開発」の枠組み の中で，てれらの翻訳作業を実施した。ての成果に関し ては，別途取りまとめを進めている。

\section{2. 土地制度の概要}

インドネシアに扔ける土地に関する制度・慣習は, 多 様な地方性をもつ慣習に加えて, オランダ植民地時代の 制度や, 独立後の制度が錯綜し, 網羅的な土地台帳の整 備を欠いたまま，現在に至っている。

現在の土地制度の法的根処々なっているのは，1960 年土地制度基本法 (UNDANG-UNDANG POKOK AGRARIA）であり，土地に関する権利として，次のも のが定義されている。

(1) HAK MILIK (所有権)

(2) HAK GUNA USAHA (経営権)

(3) HAK GUNA BANGUNAN (建設権)

(4) HAK PAKAI (利用権)

(5) HAK SEWA UNTUK BANGUNAN(建設のため の貨借権)

(6) HAK MEMBUKA TANAH (開拓権)

(7) HAK MEMUNGUT HASIL HUTAN (森林伐採 権)

(8) HAK GADAI （慣習的な質権）

(9) HAK USAHA BAGI HASIL（慣習的な小作権）

*(こばやしひでゆき・正会員 建設省建築研究所第一研究部) 
(10) HAK MENUMPANG （慣習的な無償の宿泊権）

(11) HAK SEWA TANAH PERTANIAN （農業のた めの賃借権)

また，その他の政令で規定される権利として，次のも のがある。

(12) HAK PENGELOLAAN (住宅地開発・分譲権)

(13) HAK PENGUSAHAAN HUTAN (森林経営権)

(14) HAK PERTAMBANGAN (鉱業採掘権)

これらのうち，住宅・都市開発で通常問題とされるの が(1)(2)(3)(4)(12である。

(1) 所有榷は, 最も強い権利であり, 通常個人に対し て与えられるが, 政府銀行, コーポラティブ, 宗教団体 にも与光られる。期限の制限はなく, 相続される。首都 ジャカルタでは, 新たにての権利を与えない政策をとっ ている。

てれ以外の権利は, いずれも期間に制限があり, 特定 の用途を想定していて，基本的には公有地，という考兑 方である。

(2) 経営権は, 個人・企業に与元々，農業, 漁業, 牧畜業を主に想定している。期間は, 原則 25 年, プラン テーション等で35年，更に25年間の延長が可能。

(3) 建設権は, 個人・企業化与光られ, 建築老想定し ている。期間は30年であり，20年間の延長がありうる。

(4) 利用権况, 個人・企業江与兄られ, 外国人 · 外国 企業にも与えられる。農業・林業等を想定している。政 府の土地の場合，期間は10年(特別な場合 20 年)である。

(12) 住宅地開発・分詨権は，1965年の土地制度大臣令 第 9 号で定められる権利で, 住宅地開発炎行う政府部局 または政府によって指定された法人に与えられる。その 期間に制約はない。

個人が，住宅建築を行う場合，(1)または(3)を取得する のが通常である。デベロッパーの場合は, (12)を取得し, 開発終了後, 分譲の段階で, (1)または(3)を入居者が取得 する。

(2)及び(4)の権利が取得されていれば，その土地の上に 建築炎行うことが可能である。都市計画との関量では, 市街化を予定している区域関しては(3)及び(12)が与え れ，それ以外の区域に関しては，(2)及び(4)が与えられ る，という運用がなされているょうである。 後述のように, 実際の都市及び農村には, 上記の権利
のいずれにも所属していない, 未定義未登記の土地が広 沉に存在している。乙の法律の中では, この法律の施行 以前の土地の権利状態に関しては, 次のような分類がな されている。

\section{(1) 西洋的権利に準拠した土地の権利}

(1)HAK EIGENDOM (所有権)

(2)HAK OPSTAL (地上権・建設権)

(3)HAK ERFPACHT (利用権・賃借権)

これらは，オランダ植民地時代に導入された権利であ り, 登記・権利書といった形で証明が可能な形態であ る。

\section{（2）インドネシアの土地の権利}

(1)HAK MILIK ADAT (慣習的な所有権)

(2)HAK GOGOL TETAP (固定的な世襲権)

(3)HAK PEKULEN (旦那権)

(4)GRAND SULTAN (王権)

(5)HAK GOGOL TIDAK TETAP (輪番制の世襲権) (6)GRAND CONTROLEUR（領主権）

てれらは，登記されて扔らず，権利書もなくまた境 界線も不明確な状態洫る。またてれ以外にも, 地方に よっては, 特殊な権利形態が存在する場合がある（上記 のような慣習的な諸権利について, 法律・解説書に扣い ても, その名称が挙げられているのみであって, それら の具体的な内容・性質について站記述はなく, ジャカル 夕の内務省土地問題研究所で質問しても, 明快な回答は 得られなかった)。

これらの從前の諸権利形態のそれぞれに関して，との 法律で規定する土地の権利のいずれかに整理するため に，上記の土地制度基本法の中で下記の方針が出されて いる。

(1)西洋的権利に由来する土地の椎利

(1) HAK EIGENDOM

一外国人 $\rightarrow$ 利用権

—ーンドネシア人 所有権，また纹1980年を期限 とする建設権

(2) HAK OPSTAL $\rightarrow 20$ 年期限の建設権

(3) HAK ERFPACHT

一農地 $\rightarrow 20$ 年期限の建設権

一宅地一一国の土地 $\rightarrow 20$ 年期限の建設権 一私 有 地 $\rightarrow$ 所有権

このように，西洋的権利に準拠した土地の権利に関し ては，その多くが1980年を期限とする権利に変換されて 打り，その後は，国によって経営支配される土地とな 
る。との土地の経営方針に関しては，1979年大統領令第 32号によって，近代的な土地の権利への変換の方針が出 されている。この国の土地を何らかの形で利用しようと する者は, そのための権利取得の申請手続きを経て, 権 利を取得するととになる。この権利供与は, 土地利用計 画に沿って成されるととになる。またその際に，登録 料, 毎年の義務金, 事務手数料が支払われる。な抏，乙 の大統領令の性格を見ると, 原則的に本人が直接利用し ている土地に関しては，都市計画等に支障のない限り， 原則的に申請に基づいて旧地権者に何らかの権利が与え られるが，不在地主は認めない方向であり，特に後述す るカンポンのように，既に住宅地化している土地に関し ては，そこに居住している人々に優先的に権利を与える 方針か打ち出されている(第 5 条)。

(2)インドネシアの土地の諸䉜利に関しては, 原則的 ห,

(1)(2)(3)(4) $\rightarrow$ 所有権

(5)6) $\rightarrow$ 利用権

という方針である。ただし，次のような条件が課され る。

1. KITIR, GIRIK, PETU(これらは, 旧制度時代 の納税証明に由来するものと思われる。意味は，「札」

「鑑札」等である), 土地産物税納税証明といった権利 の証拠が提示できるとと。

2. 申請の正確さと, その土地の上での権利に関する ルラ (村長または町長) 及びチャマト（郡長または区 長) の証明

3. 2 力月間の広告期間内に, 他者からの苦情または 抗議がないとと。

\section{3. 建築許可制度と建築の実態}

建築物の登録制度は存在さず，とれに代わるものとし $\tau$, 建築物の建設時に取得する建築許可書 (IJIN BANGUNAN) が，建築物の所有権の証拠と見做され ている。この建築許可書はまた, 建築物に水道や電気を 接続する際にも, 必要とされ, てれを取得していない住 宅（非常に多い）の場合, 他の家から個人契約で接続す る等のやり方が見られる。建築許可の制度は, オランダ 植民地時代に導入されたもので, 地方建築条例の形をと っていた (BOUWVERORDENING)。

現在でも, 多くの主要都市では, 1945年の独立後も, 旧 来のオランダ語で書かれた地方建築条例が，インドネシ
ア語に翻訳され，そのまま用いられている（PERATURAN BANGUNAN DAERAH)。

例えば，ジャカルタ市の場合，1929年の建築条例が独 立後も使われている。バンドン市の場合，1929年のオラ ンダ語建築条例が，1953年にインドネシア語に翻訳され ている。メダン市の場合, 1914年建築条例 (MEDANSEHE BOUWVERORDENING) が基になっている。パダ ン市の場合1916年のシャワ政庁令が基になっている。

一方，国レベルでは，建築法の制定はまだ実現して拉 らず，現在その素案が検討されている段階にある。てれ に代わるものとして，1965年に定められた国家建築施行 規則 (PERATURAN BANGUNAN NASIONAL) が ある。これは，全国共通に適応される規則として立法化 されては扣らず, 地方建築条例のモデルとして位置づけ られて扣り，公共事業省局長が組織したチームが作業に 当たったもので, バンドンの建築問題研究所（現在の人 間居住研究所）が作業の中心となった。との作業の動機 として, 従来の各都市の建築条例か現在の建築技術の実 情に合わなくなり，建築指導の内容と条例の記述に矛盾 が生じているととが，同施行規則の序文に述べられてい る。

上記の各地方都市の条例の例を見ると, 概ね1970年代 に改正（条文の追加）が行われ，特にバンドンとメダン では，技術的な記載が大幅に詳しくなっており，上記の 施行規則の影響によると考えられる。特に，建築問題研 究所の膝元にあたるバンドン市に対しては，1973年に同 研究所から, 建築条例案が提示されている。

近年では, 公共事業省の依頼により, ガジャマダ大学 が全国主要都市の建築条例案を作成し，ウジュン・パン ダン市 (スラウェン島)がてれを採用している。また， 現在では, バンドン工科大学が，その他の中小都方を対 象として, 建築条例案の作成作業を行っている。乙れら は, インドネシアが内包する多様な地方性（自然条件・ 文化的条件）の違いに対処するためには，地方の条件を 考慮した条例での対応が重要であるととを示している。 パダン市に提示されている条例案を見ると, 全体が 252 条から成り，現行の全 12 条例と比較して，特に技術的な 面で大幅に詳細化されている。

一方, 建築条例の実際の実施状況を, 年間許可件数と 実際の推定住宅建設戸数の比率汃ら推定する（建設戸数 を世帯数増加 $\div 2$ と仮定）と，1984年シャカルタでは 9 -14\%, 1985年バンドンでは30\%という数字が得られる。 とのととは，大多数の庶民住宅が，建築許可を取得する 
ととなしに，建設されているととを示している。

オランダ植民地時代に，建築規制が導入された時点で は，都市開発は，植民地政府が主要計画街路 (JALAN) に沿った土地を買収する形で進められていた(註 4 )。

この段階では, 公式の建築制度が適用されるのは, 買 収された街路に面する敷地のみであって，その裏側に残 された土地と，そとに居住する土着インドネシア人の住 居（カンポン＝集落）は制度の対象外であった。独立後 には，乙のような制度上の区別は，少なくとも理念的に は廃止されたが，しかし建築線制度を主要な内容とする 独立以前からの内容を受け継いだ上記の地方建築条例の 枠組みの中では, 直ちにカンポン住宅が建築許可の現実 的な対象となるには大きな落差が存在して招り，その状 況は基本的に現在まで受け継がれている。

まず第一に, 土地が限定され, 裯密に建て詰まったカ ンの中で, 細い路地 (GANG と呼ばれる) により到達 する住宅は，建築線の概念とは適合しない。また，1970 年代に新たに追加された建築材料・構造等に関する規定 は，粗悪で安価な材料や，中古の部材を多用するこれら の住宅の水準にとって, あまりに高すぎる。

第二に, カンポンでの建設は，小さな增改築の連鎖と いう形をとっている。てれは, 着工・竝工を明確に規定 する建築許可の体系とは, そもそも馴染まない性質であ る。

第三に，現在の建築許可の手続きの実際を見ると，計 画許可 (都市計画局), 土地権利の証明 (土地制度局), 建築設計の審査 (建築許可局) を経過しなければなら ず，多大の費用と時間を必要とし，また土地の測量に打 いて, 別の部局に提出するために同じ敷地学測り直さな ければならないようになっているなど, 収入の低い䳸民 にとっては，手の届きにくいものである。

しかし, カンポンの個別調査の結果によると(註 2 ), 個々の建築活動蛙, 必ずしも無届けで行われているので はなく, 多くの場合工事開始に先立って, 近隣, 打よび 自治会の長住して事前報告が行われ，口頭での承認が 与えられている。てれを以て, 建築許可と了解している 場合も多い, と推定できる。即ち, カンポンでの建設活 動が公式の建築許可を得ていないととは, それが無秩序 に行われているととを必ずしも意味しない。

\section{4. 不動産課税の変遷}

インドネシアに㧍ける不動産課税の歴史は, オランダ 植民地時代に遡る。初期のオランダ東印度会社 時代に
は, CONTINGENTEN (臨時税), VERPLICHTE LEVERANTTIEEN (義務的貢献) 等の, 様々の税が徴 収された。とれらは、ジャワ戦争 (1825-30年) の原因 となった。英国合併時代には，提督ラッフルズにより， LANDRENT (地代) と呼ばれ, オランダ領東印度時代 には, LANDRENTEと呼ばれた。独立後, この体系 は, PAJAK BUMI (土地税), 更に PAJAK HASIL BUMI (土地生産物税) と名称変更された。

この税体系は, 地価ではなく, 土地やその上の建築に よる生産に対する課税であって, 同時に存在していた PAJAK PENGHASILAN (所得税) と重畳するため, 戦後1952年に至って廃止された。

しかし，政府の収入を確保する必要から，1959年に は, PAJAK HASIL BUMI が再び徵収されるようにな った。ただし, 廃止前のものとは異なり,てれは地価に 基づいて徵収されるものであった。地方分権・自律化の 流れの中で, この税は, IPEDA (地方開発寄付金) と名 称変更された。徵収の主体は, 中央政府であるが, その 収入は，主に開発資金として，地方政府に交付された。 ての段階に至っても, その法的根拠は脆弱であり, 法律 は存在せず，地方条例をその根拠として扣り，戦前から の, 不動産に関係した VERPONDING, INLANDS VERPONDING, PAJAK HASIL BUMI等に代わるも のとされながら，それらは正式に廃止されないままとな っていた。

地方政府の収入源である IPEDA は, その10\%が評価 と徵収費用に充当され, 残りの正味のうち10\%が州政府 に，また $90 \%$ が指定都市 (KOTAMADYA) あるいは県 (KABPATEN) に交付された。

1983 年度の政府歳入で見ると, 全体の $63.4 \%$ が直接 税, $12.6 \%$ が間接税, $2.8 \%$ が税以外の収入, 以上合計 $78.8 \%$ が国内からの収入であり，てれに加え $21.2 \%$ 開 発資金援助によって支光られている。直接税の大半 (全 体の52.0\%) 占めているのが国営石油企業からの税収 入であり，てれと国際援助を合わせると，73.2\%とな る。一方, IPEDA 等の不動産税を含むその他の直接税 の比率は，5.1\%占めるに過ざず，乙れは1973年度の $7.0 \%$ 加引額に扣いては增加するものの，之の比率に扢 いては減少する傾向にある。

不動産税の徵収実績の, 潜在的可能性に対する比率を 見ると，14\%と, 諸税の中で最低になって扣り, 徵収が 難しい状況を示している(註 3 )。

納税の普及を阻んでいる背景の一つは, 様々な種類の 
税が錯綜し，税体系自体が混在し，納税者や徵税官にと ってわかりにくく，加重複と矛盾に満ちた体系となっ ている点が指摘されている。

石油価格の低迷により，歳入が大幅に低下したインド ネシア政府では，諸税制の改革に本格的に取り組んで扔 り, 矢継ぎ早化, 旧個人・企業所得税化代わる新所得税, 旧取引税に代わる付加価值税が導入されており，ての新 土地家屋税制の導入もそのような経済情勢の流れの中に 位置づけるととができる。

しかし，新税制注，単に税収入を増加させるととだけ が目的ではなく，少なくとも理念としては，従来の政府・ 公務員のための収入確保を超えた，開発計画への支出に よる資本形成，所得と福祉の再配分による公平化，な どが謳われている(註 5 )。てれらについては，6で触れ る。

\section{5. 新たな法律の構成と税制の概要}

上記の法律は全31条から成り，以下の構成である。 PASAL (条)

1. 定義

2 . 課税の対象

3. 除外される対象

4. 納税者

5. 税率

6. 税の算定基準となる価格

7. 税額の算定

8. 算定基準日, 所管の自治体

9. 課税対象の申告

10. 課税対象申告書と課税決定通知書

11. 納税期限, 未納の扱い, 納税場所, 督促

12. 督促状

13. 強制

14. 督促の権限の自治体の長への委任

15. 過重

16. 過重の申告

17. 裁決に対する裁判所への抗議

18. 税収入の中央・地方政府間配分

19. 税の減免

20. 罰金の減免

21. 役所の義務

22. 役所への制裁

23. 1983年第 6 号法の定義の有効性

24. 急慢
25. 故意の違反

26. 時効

27. 反則と違反の定義

28. 地方開発寄付金，財産税，世带税との関係

29. 地方開発寄付金の根拠法との関係

30. 採掘利益税との関係

31. 施行日

\section{(1) 課税の対象}

課税の対象は，土地と建築である。ただし，(1)教育・保 健・社会・宗教施設, (2)古代の遺跡等, (3)保護林・避難 林・観光林・国営公園・村有の牧場・権利の設定されて いない国有地，(4)領事館等，(5)国際機関は除外され， また個々の取引価格が 2 百万ルピア未満の建築に関して は，対象から除外される。

\section{(2) 納税の主体}

納税の主体は，土地の上に明確な権利を有する個人ま たは組織，且つ/又は土地の上で利益を得る個人又は組 織, 且つ/又は建築を所有・経営する個人又は組織, 且 つ/又は建築加ら利益を得る個人又は組織，となってい る。課税対象が納税義務者にまだ知られていない時に は，税務署長は，納税義務者を決定することができる。 てれに対し，決定された者は，根拠資料を添えて反論す るととができ，てれに対する税務署長からの承認または 拒否が 1 ケ月以内になされない場合には，自動的に反論 が承認されたものとする。

\section{(3) 税額の算定}

税率は $0.5 \%$ である。

課税の基礎は, 課税対象の取引価格で, この取引価格 は, 財務大臣によって 3 年毎 (ジャカルタ等の地価変動 の激しい特定地域では，毎年）飞決定される。

課税取引価格は，取引価格の20-100\%の間で, この百 分率は，国の経済の状態を考慮して政令で決定される。

税額は，課税取引価格に税率を掛けたものである。

\section{(4) 課税対象の申告}

課税対象として決定された場合, 納税義務者は, 送付 された課税対象申告書に必要事項を記入し30日以内に返 送し，課税対象を登録しなければならない。との提出が ない場合，または過少申告が明らかな場合には，税務署 長は，課税決定書を送付する。その場合，25\%の追徴金 が追加される。

\section{（5）税収入とその分配}

税の地域区分は, ジャカル夕首都特別地域に扣いて 
は，区(WILAYAH)，その他の地方に扔いては，第二 旧行政地域（県 $=$ KABUPATEN，又は指定都市= KOTAMADYA) である。財務大臣は, 督促の権限を自 治体の長に委譲するととができる。徵収した税は，中央 政府と地方政府の間で配分し，地方政府に対する配分 は，90\%以上を確保する。

\section{(6) 既存の不動産税との関係}

1985 年及びそれ以前に課された地方開発寄付金 (IPE DA), 財産税 (PRK), 街路税, 世帯税 (PRT) に関し ては，1990年12月31日まで課税の法令は有効である。ま た，既存の「土からの利益に関する1959年法律第11号」 に基づく地方開発奇付金に関連する法令は，乙の新しい 法律に基づいて今後施行される政令に反せず，西るいは それらがまだ発効しない間は，1990年12月31日まで有効 である。

\section{6. 新税制の目的と新たな方向}

この新しい土地家屋税制が，実際にどのように施行さ れ，どのような経済的効果をもたらすかは，まだ実施さ れたばかりの現段階では明らかではない。しかし，少な くとも制度そのものの中にいくつかの理念を見るととが でき，インドネシアに扰ける新たな方向を知るととがで きる。

\section{(1) 諸制度の簡略化の方向}

インドネシアの住宅に関連する税制を見ると, 地方開 発寄付金, 地方復興寄付金, 建築線税, 街路税, 世帯税, 街灯税等の様々の小額の税が錯綜し, 多数の公務員が関 係している。税制に限らず，建築許可の手続きに扔いて も, 都市計画局, 土地局, 建築許可局にまたがる煩雑な 手続きや重複する土地測量があって, 多大の費用と時間 を必要とし，その一般化を阻む原因となっている。

ての税制は, 従来のいくつかの税制を統一し, 簡略化 するものである。オランダ植民地時代以来の翻訳による わかりにくい法律から脱却し, 税額の算定も極めて単継 明快なものとなっている。納税義務者の権利と義務を規 定する一方で, 役所の側の義務と権限の範囲も規定して いる。また，例えば役所の決定に対する納税者側からの 反論に対する役所からの回答に期限が設けられ, 回答の ない場合には承認と見做すなど，迅速な対応への配慮が 認められる。乙れは, インドネシアの政府側にも, 複雑 過ざる手続きと遅い対応に問題がある，との認識がある てとを示している。

\section{(2) 地方の自律}

上記のように，ての新しい制度による税収入の $90 \%$ 以 上は，地方政府の財源となる。てのて々は，てれまでの 国営石油企業の収益及び海外援助に依存した, 中央政府 による予算配分を経由した地方開発と比較して，より大 きな地方の自律の可能性を開くものである。従来は，住 宅政策に打いても，国営住宅公社 (PERUM-PERUMN AS）による住宅建設と国民貯金銀行（BTN）によるデ ィベロッパーを介しての住宅融資，及び海外汃らの援助 に支えられた環境改善を内容とするカンポン改善事業が 柱であった。例えば, 国営住宅公社の標準設計や, 融資 の規準となる標準設計は, 全国画一であり, 多様なイン ドネシアの地方性に詨応する，という観点はそこにはな かった。「国の統一」のテーゼの枠と，てれからの地方 政府によるとの税収入の運用に，どのような地方独自の 開発手法が展開するか恃, 興味のある問題である。

\section{(3) 所得の再配分の考え方}

インドネシア社会では, 広い屋敷に住む富豪層とカン ポンに住む低所得層の間の大きな所得格差があり, これ が物的な都市構造にも明確に現れている。相続税は存在 せず，ての格差は保存される傾向にある。

従来の住宅政策に扔いても，住宅注個人の財産である との基本的な考えから，公的住宅は分虽が原則であり， 日本・中国・韓国・シンガポールのような最低所得階層 在対象とした公的賃貸住宅の方式 (所得の再配分を前提 とした住宅政策) 受け入れ難く, 分譲住宅も価格的には 最低所得階層にとって乎の届かないものとなってきた。

しかし, 団地内部で比較的所得の高い階層を対象とし た住戸と低所得階層を対象とした住戸芭混在させ，之の 間の価格設定で所得の再配分寺図るという，CROSSSUBSIDY の考光方は存在し，実際にそのような団地が 国営住宅公社により建設されている。

この新しい税制の中では，正式の権利が設定されてい ない公有地, 及び 2 百万ルピアに満たない建築は, 課税 対象から除外されて抢り, カンポンの住宅の多くは, 当 初から除外された，と考えるととができる。つまり，大 多数の低所得階層加引, 土地家屋税苍徵収しないとと になる。

\section{（4）自己申告制度と開発利益の還元の可能性}

従来, 国営住宅公社による大規模団地開発に付随し て, その周辺地域に中小民間ディベロッパーによる住宅 開発が派生し, 公的住宅のためのインフラストラクチュ ア整備に「只乗り」する傾向があった。このため, 低所 得層を対象とした住宅開発の利益を, むしろ周辺に派生 
した民間住宅の比較的所得の高い階層が享受する，とい う現象も見られた。とのような状況は, 上記のCROSSSUBSIDY の考元方とは矛盾するものである。てれに対 し現在, LAND-CONSOLIDATION (土地区画整理+ CROSS-SUBSIDY+土地銀行) による対応等が提案さ れている。

開発やインフラ整備による周辺の利便を反映した地価 上昇に対して有効な課税が行えれば，乙れを事業費の一 部として，西るいは事業の際に受けた融資の返済源とし て還元できるはずである。

従来の地方開発寄付金では，実務上てのととが充分に は実現できなかった。

この新しい税制の中では, 税額の計算が, 取引価格を ベースに行われている。従って, 不動産の売買が生じた 時点で, その佂格上昇は影在化するととになる。仮に過 少申告と納税が行われていたとしても, 取引が生じた時 点で, それは明らかとなり, 遡って徵収されるてとにな る。また, その納税証明がなければ売買に際しての, 登 記の書換えはできない。従って, 納税者側にとっては, 地価が上昇した場合に, その時点で納税するか, 後日売 買の時点で, まとめて精算するかの選択しかあり得ない てとになる。つまり, 理論的には, 開発利益が税によっ て還元できる仕組みとなっている。てれが実際に機能す るかどうかについては, 今後の推移が興味深い。

\section{7. 最近の動向}

ての新しい税制は, 様々な面で制度の近代化を試みつ つ, 少なくとも「徴税」に関しては, 低所得階層を免除 しつつも, その税額を増加させ, その実施に当たっての 法的な根拠を強化するものであった。現在, 初年度の徴 税を終え, ラジオ等でも地方別徽税状況等が放送された りしている。まだ，全体的な評価をする段階には至って いないが，1987年 7 月 9 日付けの「コンパス」紙に，国 民の反響と政府側の対応に関する記事が記載されたの で，紹介する。

「世界銀行は， 3 都市で 6 万棟の建物の土地家屋税を算 定する」(ジャカルタ)。

ジャカルタ, メダン, バンドンの 1 万棟の大規模建 築, 及びジャカルタの 5 万棟の中規模建築について, 土 地家屋税制の納税義務額を評価するために, 地方開発寄 付金との比較で査定するとととなった。ての評価の実施 は, 国内外に開かれた国際入札に基づいて, 鑑定業者に 委託される。この活動は, 土地家屋税の徵収に関する税
務局と世界銀行の協力事業の一環として行われる。

世界銀行は, 土地家屋税の評価プロシェクトと, 評価 官の教育のために，2 千 5 百万ドルを援助する。乙の援 助は, 土地家屋税を磪実に徵収できれば, 国民の潜在力 を集約できるというインドネシア政府と世界銀行の共通 の認識に基づいている。特に地方政府にとっては, 徵収 額の $81 \%$ がもたらされる。

その国際援助資金の使途は既亿決定されて打り，

(1) 土地家屋税の対象物件の評価政策を定めるために, 外国の専門家を探す。

(2) ジャカルタ, メダン, バンドンで, 1 万棟の大規模 建築を評洒する。

(3) ジャカルタで， 5 万棟の中規模建築学評価する。

(2)(3)の業務に関しては, 国際入札により, 正しく条件 を満たす鑑定業者を決める。

国内業者の瞉慮に応えて，その入札は外国業者だけに は限定しない。外国業者が落札した場合であっても，国 内業者が共同する可能性は開かれている。父の場合, 知 識と経験を吸収する利益が国内業者にもたらされる。外 国業者にとっても，単独で鑑定するととは，鑑定すべき 建物の状態や地域の実情を把握するために，より多くの 時間を費やすととにならう。

地方開発寄付金の評価を行ってきた担当者たちは，土 地家屋税の評価の担当として活用できる。世界銀行のも う一つのプロジェクトは, 地方開発寄付金の全ての評価 担当官の訓練である。その訓練担当者住, 国内から採用 し，外国の監督者をてれに添える。その訓練のために， 税務局は, 既にマレーシアから30人の無償派遣を取りつ けて打り，往復旅費だけを負担するてととなっている。

現在, 土地家屋税の実施に対して, 国民から多くの不 満が奇せられているととを政府は否認しない。地方開発 寄付金と比較して，より高額であることが不満の原因で ある。しかし，地方開発寄付金とだけ比較してはならな い。土地家屋税は，財産税を含むいくつかの税金を統合 単純化したものである。

税の返却について。

（中略）

歴史的に見ると，新しい税法が施行された時点では， 将来に向けて計画されている。考えられるべき第一の論 点は, 古い法律と新しい法律の間に一線を画して欲し い,というととである。過去に行われた納税義務はもは や問題とされず，新しいものが適用された時点では，一 掃されている。従って, 税の目てぼしは, 今後ない。 
第二に，新しい法律の施行の初めに岕たって，納税義 務者が，安全かつ健全であるととを政府は望んでいる， というととである。税の担当官の行動によって, 不安が もたらされてはならない。そのために，1984年 3 月 1 日 以来，税の担当官は，納税者にすな打に関係するてとを 宣言し，また向う 2 年間，納税者を悩ませず，検査業務 等で困らせないととを約束した。

第三に，政府统，納税者が義務之権利苍同時に受ける 地位にあるとと望んでいる。つまり，納税者が正しく 税を支払うととによって政府を支援する場合には，政府 もまた納税者が困難の中にあるときに，援助を与えるの である。

との文脈の中で, 1984年度のための返還供与を促進 し，1986年の評価替光後に経営者に再評価の機会を与え よう。政府は，方の時点に確実にある困難を見込んでい るので，鑑定を行う前に，返還を行う。2 年間の間安心 していて欲しいととを，政府は重ねて付け加える。

ての政策の枠組みの全ての結果は，現在確実に見えて いる。1984年度の税収は 3 兆に過ぎなかったものが，現 在では 6.1 兆である。個人の所得税納税者は, 1984年 1 月には，327,547人だったものが，現在（1987年初頭） では643,042人となった。法人の所得税納税者は, 83, 642 から 157,584 法人に増加し，21条所得税（企業に天引き される従業員）注，94,474から193,492人に增加した。 （以上は，コンパス紙記者の質問に対する，財務省税務 局長サラムン氏らの回答である)

\section{8. まとめ}

現在，主に石油価格に起因する政府財源の伸び悩みか
ら, 政府の住宅政策の方向も, 直接建設をより限定的に 考え, むしろ大多数を占めるカンポンの中での自力建設 を支援する方向倾斜しつつある。その中で, 地方自治 単位の果たすべき役割は重要と考えられてきて抢り，そ れを支援するための情報提供や人材養成などが，中央政 府の重要な役割と考えられている。

新しく導入されたての土地家屋税制は, 地方の自律を 目標の一つとしたものであり, その意味で, 多様な地方 性を内包するインドネシアに扣ける住宅都市開発の在り 方に対するインパクトが注目される。

\section{註䣋文献：}

註 1 : UNDANG-UNDANG RI-PBB-BM TAHUN 1985 政府刊行物

註 2 : 「低所得層のための住宅開発の法制の研究 (PENELITIAN PERATURAN DAN PERUNDANG-UNDAN_ GAN PEMBANGUNAN BAGI MASYARAKAT BERPENGHASILAN RENDAH) $\rfloor 1986$

註 3 : U.S. UPPAL: “TAXATION IN INDONESIA” 1686 註 4 : TJONDROSUGIANTO PARWOTO : "HOUSING ARRANGEMENT FOR LOW-INCOME URBAN FAMILIES" INSTITUTE OF SOCIAL STUDIESHAGUE NETHERLANDS 1981

註 5 : PROF. DR. H. ROCHMAT SOEMITRO,S.H. : "PAJAK BUMI DAN BANGUNAN" 1986 なお，税額の実態に関して，たまたま面識のあるスラバヤ のS講師によれば，同氏の屋敷に対して，昨年度までは， 35 千ルピア/年の IPEDA を払っていたが，今年は，57干ル ピア/年の土地家屋税を払ったそうである。 その他の文献：

R. ATANG RANOEMIHARDJA, SH : "PERKEMBANGAN HUKUM AGRARIA DI INDONESIA" 1982

K. WANTJIK SALEH: "HAK ANDA ATAS TANAH" 1977 